\title{
Transient parkinsonism in isolated extrapontine myelinolysis
}

\author{
Bart Post $\cdot$ W. A. van Gool $\cdot$ M. A. J. Tijssen
}

Received: 24 April 2008/Accepted: 15 April 2009/Published online: 15 May 2009

(C) The Author(s) 2009. This article is published with open access at Springerlink.com

\begin{abstract}
Extrapontine myelinolysis (EPM) is a rare cause of parkinsonism. In this case report, we describe a 63-year-old woman with parkinsonism due to EPM after correction of hyponatremia. During a 4-year follow-up, both the clinical features of parkinsonism and the changes on magnetic resonance imaging resolved. Parkinsonism due to EPM should be recognized as it has a good prognosis.
\end{abstract}

Keywords Parkinsonism · Extrapontine myelinolysis . Hyponatremia

\section{Introduction}

Parkinsonism is mostly due to Parkinson's disease, vascular parkinsonism, dementia-parkinsonism or druginduced parkinsonism. Other than drug-induced causes of secondary parkinsonism account for a small percentage of cases of parkinsonism and can be due to several causes. One of the possibilities is extrapontine myelinolysis (EPM). Myelinolysis results from rapid correction of hyponatremia and is generally located central in the pons, so-called central pontine myelinolysis (CPM) but can also be located outside the pons (EPM). Here, we describe a

B. Post - W. A. van Gool - M. A. J. Tijssen

Department of Neurology and Clinical Neurophysiology,

Academic Medical Center, Amsterdam, The Netherlands

B. Post

e-mail: b.post@amc.uva.nl

M. A. J. Tijssen ( $₫)$

Department of Neurology H2-222, Academic Medical Center, P.O. Box 22660, 1100 DD Amsterdam, The Netherlands

e-mail: m.a.tijssen@amc.uva.nl case of parkinsonism due to EPM without CPM with 4-year clinical and radiological [magnetic resonance imaging (MRI)] follow-up and we review the recent literature on this subject.

\section{Case report}

A 63-year-old woman was admitted to the hospital because of nausea, vomiting, difficulty speaking and impairment of coordination of her arms and legs. Laboratory studies showed a severe hyponatremia of $104 \mathrm{mmol} / \mathrm{l}$ which resulted in an acute metabolic encephalopathy. This was corrected initially using hypertonic $\mathrm{NaCl} 1.5 \%$ and later using isotonic $\mathrm{NaCl} 0.9 \%$ infusions. After $18 \mathrm{~h}$ the sodium concentration raised to $121 \mathrm{mmol} / \mathrm{l}$ and $36 \mathrm{~h}$ later it was $130 \mathrm{mmol} / \mathrm{l}$. During 1 week of hospitalisation, she experienced an improvement and was discharged from the ward with a slight dysartria. In the past she had been diagnosed with breast carcinoma, diverticulosis and had undergone a cholecystectomy. Furthermore, she suffered from hypertension and was on drugs for this: B-blocking agent and diuretics (triamtereen-epitizide). The use of diuretics in combination with the vomiting was thought to have caused the severe hyponatremia and the drugs were discontinued.

Eight days later she was readmitted to hospital with progressive dysartria, bradykinesia and loss of "strength" of her arms and legs. Within several days she deteriorated to a bed-ridden stage. Two weeks after this deterioration, without a clear diagnoses, she was referred to the neurology department in our hospital.

During neurological examination the patient was alert and well-oriented. MMSE was 28/30, where she lost two points on memory and visuo-construction. She had a masked face and hypo-phonic speech. Examination of the 
Fig. 1 Top T2-weighted magnetic resonance scan image showing bilateral symmetrical hyperintensities in caudate nucleus and putamen with sparing of the pons; there is also typical sparing of the pallidum. Bottom T2-weighted magnetic resonance scan after 4 years of follow-up showing a normal intensities of caudate nucleus, putamen and pons
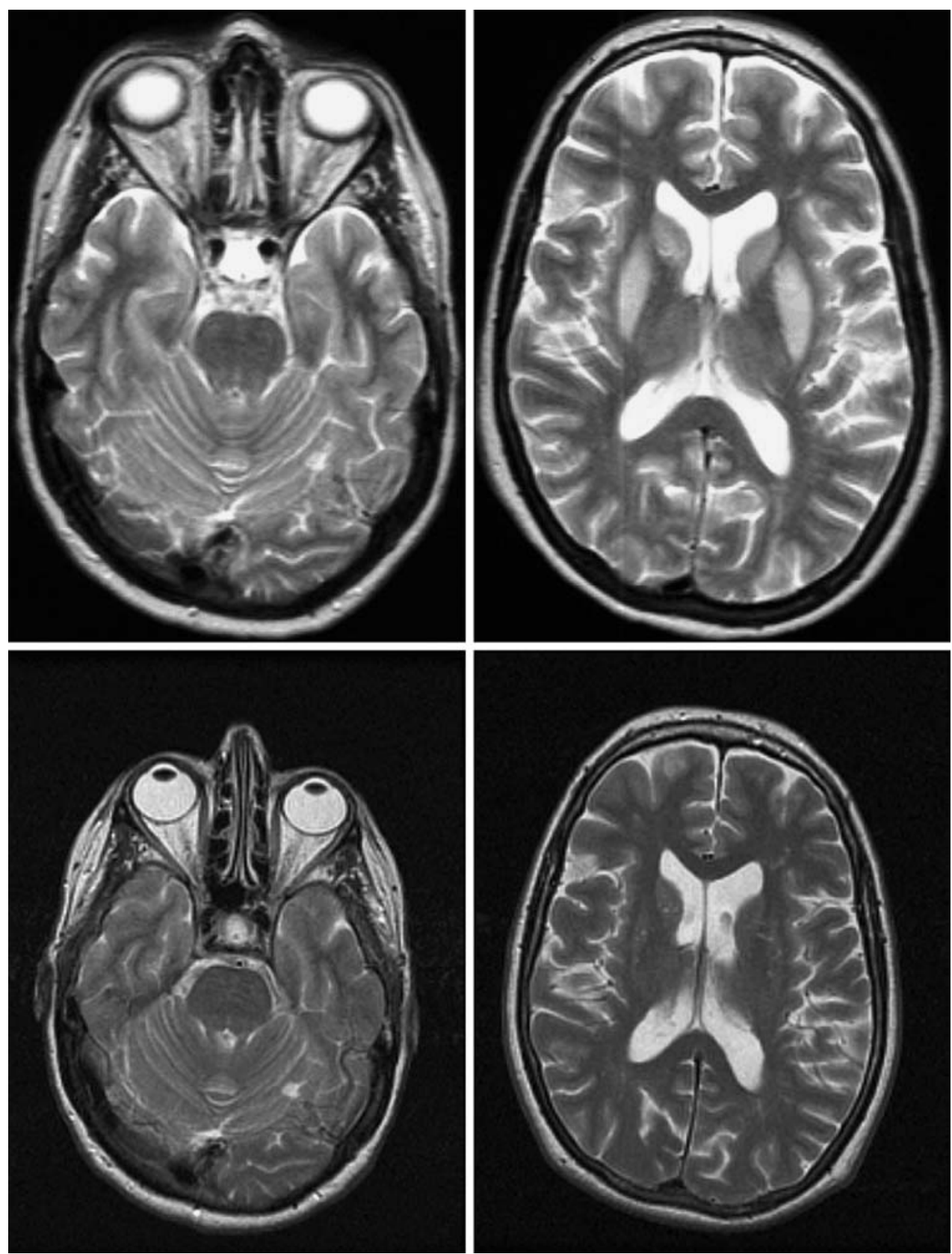

cranial nerves showed no abnormalities, with normal eye movements. Her upper and lower limbs showed, left more than right-sided, rigidity with cogwheeling and bradykinesia. She had difficulty raising from a chair, and when walking her armswing was decreased. The postural reflexes were impaired. No tremor, dystonia or dyskinesias were noted. The remaining neurological examination was without abnormalities.

Blood tests showed no abnormalities. Sodium was $142 \mathrm{mmol} / 1$, potassium $3.5 \mathrm{mmol} / \mathrm{l}$, ceruloplasmin and copper were normal, thyroid function and lactate in blood were normal, as was the chest X-ray. The T2-weighted images of the MRI of the brain showed bilateral and symmetric increased intensities in the nucleus caudatus and the putamen with sparing of the globus pallidus (Fig. 1, top). There was no abnormal signal in the pons (Fig. 1, top). T1-weighted images of both regions were normal.

Based on the clinical course, history of hyponatremia with correction and the abnormalities on the MRI-scan the diagnosis EPM without CPM was made. The patient recovered slowly and was discharged home with parkinsonism; dysartria, bradykinesia and rigidity. During followup at the outpatient clinic the patient gradually recovered from her parkinsonism. Three years and 9 months after discharge neurological examination showed only a mild masked face, but further neurological examination was 
Table 1 Cases described in literature from 1990 until now with parkinsonism due to EPM without CPM

\begin{tabular}{|c|c|c|c|c|c|}
\hline Article & Cause of hyponatremia & Hyponatremia & $\begin{array}{l}\text { Lucent interval } \\
\text { between correction } \\
\text { hyponatremia and } \\
\text { start myelinolysis }\end{array}$ & Follow-up & Prognosis \\
\hline $\begin{array}{l}\text { Post }(2009) \\
\quad \text { (current } \\
\text { case) }\end{array}$ & Diuretics and vomiting & $\begin{array}{l}\text { Initial: } 104 \mathrm{mmol} / \mathrm{l} \text {; correction to } \\
121 \mathrm{mmol} / \mathrm{l} \text { in } 18 \mathrm{~h} \text { and to } \\
130 \mathrm{mmol} / \mathrm{l} \text { in } 30 \mathrm{~h}\end{array}$ & + & 4 years & Good recovery \\
\hline Sajith (2006) & $\begin{array}{l}\text { Addison's disease; exacerbated } \\
\text { by dehydration and vomiting }\end{array}$ & $\begin{array}{l}\text { Initial: }<100 \mathrm{mmol} / \mathrm{l} ; \text { correction } \\
\text { to } 130 \mathrm{mmol} / \mathrm{l} \text { over } 5 \text { days }\end{array}$ & + & 2 months & Good recovery \\
\hline Okada (2005) & $\begin{array}{l}\text { History transphenoidal resection } \\
\text { and gamma knife treatment of } \\
\text { prolactinoma; now episode of } \\
\text { pneumonia and general sickness }\end{array}$ & $\begin{array}{l}\text { Initial: } 109 \mathrm{mmol} / \mathrm{l} \text {; correction to } \\
120 \mathrm{mmol} / \mathrm{l} \text { in } 28 \mathrm{~h}\end{array}$ & + & 3 years & Good recovery \\
\hline Koussa (2003) & Diuretics & $\begin{array}{l}\text { Initial: } 99 \mathrm{meq} / \mathrm{l} \text {; correction to } \\
127 \mathrm{meq} / \mathrm{l}<24 \mathrm{~h}\end{array}$ & + & 4 months & Good recovery \\
\hline Kim (2003) & Cis-platinum and vomiting & $\begin{array}{l}\text { Initial: } 98 \mathrm{meq} / \mathrm{l} \text {; correction to } \\
128 \mathrm{meq} / \mathrm{l} \text { in } 20 \mathrm{~h}\end{array}$ & + & 4 months & Good recovery \\
\hline Salvesen [5] & $\begin{array}{l}\text { Transphenoidal resection of } \\
\text { pituarity adenoma. On hormonal } \\
\text { substitution therapy; episode of } \\
\text { water poisoning }\end{array}$ & $\begin{array}{l}\text { Initial: } 110 \mathrm{mmol} / \mathrm{l} \text {; correction to } \\
123 \mathrm{mmol} / \mathrm{l} \text { within the first } \\
12 \mathrm{~h} \text { and to } 139 \mathrm{mmol} / \mathrm{l} \text { after } \\
28 \mathrm{~h}\end{array}$ & + & 6 months & Good recovery \\
\hline Waragi (1998) & $\begin{array}{l}\text { Germinoma of the pineal gland } \\
\text { and radiation with } \\
\text { panhypopituitarism. } \\
\text { On hormonal substitution } \\
\text { therapy; adrenergic crisis } \\
\text { following cold }\end{array}$ & $\begin{array}{l}\text { Initial: } 105 \mathrm{meq} / \mathrm{l} \text { andere } \mathrm{EH} \text {; } \\
\text { correction to } 148 \mathrm{meq} / \mathrm{l} \text { in } \\
7 \text { days }\end{array}$ & + & Not stated & Not stated \\
\hline Tomita (1993) & $\begin{array}{l}\text { History of hypophysectomy after } \\
\text { apoplexy with concurrent } \\
\text { diabetes insipidus }\end{array}$ & $\begin{array}{l}\text { Initial: } 103 \mathrm{meq} / \mathrm{l} \text { andere } \mathrm{EH} \text {; } \\
\text { correction } 126 \mathrm{meq} / \mathrm{l} \text { in } 3 \text { days }\end{array}$ & - & 10 months & $\begin{array}{l}\text { Progressive } \\
\text { parkinsonism } \\
\text { without reaction to } \\
\text { dopaminergic } \\
\text { therapy }\end{array}$ \\
\hline
\end{tabular}

unremarkable. MRI at this stage showed no abnormalities on T2-weighted and FLAIR images in the nucleus caudatus and the putamen (Fig. 1, bottom).

\section{Discussion}

We describe a case of parkinsonism after correction of hyponatremia with radiological evidence of EPM without CPM with the longest follow-up reported in the literature.

EPM without CPM causing parkinsonism has been reported in Pubmed seven times since 1990 (Table 1) [1-7]. In all reported cases, including our own case, a severe hyponatremia with fast correction was described, similar to our case. In seven of these cases an initial improvement of general symptoms due to the hyponatremia (e.g. confusion, epilepsy) was described after correction of the hyponatremia, with a secondary deterioration after which symptoms of parkinsonism developed. Spontaneous recovery of this second episode occurred in days to weeks.
Six out of eight showed good recovery, which does not mean complete recovery, after a variable follow-up time.

EPM without CPM is described in $22 \%$ of cases with myelinolysis [8]. These EPM lesions were most frequently seen in the cerebellum $(55 \%)$, lateral geniculate body $(41 \%)$, putamen $(34 \%)$, thalamus $(34 \%)$ and cerebral cortex/subcortex (34\%) [8]. CPM was first described in 1959 by Adams. [9] In a series of 58 cases of myelinolysis with brain autopsy in $47 \%$ of patients myelinolysis was confined to the pons, while in $53 \%$ of patients lesions were also located outside of the pons; EPM. In 1976 Tomlinson suggested rapid correction of sodium as an etiological factor for myelinolysis [9]. Myelinolysis, however, not only appears in adult or alcoholic patients with hyponatremia but can also occur with normal or elevated serum sodium levels [10]. Nowadays it is believed that myelinolysis is caused by a dysbalance between brain electrolytes, especially sodium and chloride, and organic brain osmolites, e.g. creatine, taurine, glutamate. With the correction of serum hyponatremia a net shrinkage of the brain 
will occur. Oligodendroglial cells form a network around large neurons and appear to be vulnerable to physical stress related to shrinkage [10] leading to myelinolysis in the typical predeliction sites for CPM and EPM. This dysbalance hypothesis has led to the recommendation that correction of hyponatremia should not excess $8 \mathrm{mmol} / \mathrm{l}$ per day [9].

We conclude that EPM is a rare cause of parkinsonism that occurs after an initial period of recovery after rapid correction of hyponatremia. The prognosis based, also on the long term seems favourable, although the possibility of publication bias can lead to overestimation of this good prognosis.

Open Access This article is distributed under the terms of the Creative Commons Attribution Noncommercial License which permits any noncommercial use, distribution, and reproduction in any medium, provided the original author(s) and source are credited.

\section{References}

1. Sajith J, Ditchfield A, Katifi HA (2006) Extrapontine myelinolysis presenting as acute parkinsonism. BMC Neurol 6:33
2. Okada K, Nomura M, Furusyo N, Otaguro S, Nabeshima S, Hayashi J (2005) Amelioration of extrapontine myelinolysis and reversible parkinsonism in a patient with asymptomatic hypopituitarism. Intern Med 44(7):739-742

3. Koussa S, Nasnas R (2003) Catatonia and Parkinsonism due to extrapontine myelinolysis following rapid correction of hyponatremia: a case report. J Neurol 250(1):103-105

4. Kim JS, Lee KS, Han SR, Chung YA (2003) Decreased striatal dopamine transporter binding in a patient with extrapontine myelinolysis. Mov Disord 18(3):342-345

5. Salvesen R (1998) Extrapontine myelinolysis after surgical removal of a pituitary tumour. Acta Neurol Scand 98(3):213-215

6. Waragai M, Satoh T (1998) Serial MRI of extrapontine myelinolysis of the basal ganglia: a case report. J Neurol Sci 161(2):173-175

7. Tomita I, Satoh H, Satoh A, Seto M, Tsujihata M, Yoshimura T (1997) Extrapontine myelinolysis presenting with parkinsonism as a sequel of rapid correction of hyponatraemia. J Neurol Neurosurg Psychiatry 62(4):422-423

8. Gocht A, Colmant HJ (1987) Central pontine and extrapontine myelinolysis: a report of 58 cases. Clin Neuropathol 6(6):262270

9. Martin RJ (2004) Central pontine and extrapontine myelinolysis: the osmotic demyelination syndromes. J Neurol Neurosurg Psychiatry 75(Suppl 3):iii22-iii28

10. Brown WD (2000) Osmotic demyelination disorders: central pontine and extrapontine myelinolysis. Curr Opin Neurol 13(6):691-697 